\title{
Fruit and Vegetable Intake in a Sample of 11-Year-Old Children in 9 European Countries: The Pro Children Cross-Sectional Survey
}

\author{
Agneta Yngve Alexandra Wolf $^{b}$ Eric Poortvliet ${ }^{a} \quad$ Ibrahim Elmadfa $^{b}$ \\ Johannes Brug $^{c}$ Bettina Ehrenblad ${ }^{a}$ Bela Franchini ${ }^{d}$ \\ Jóhanna Haraldsdóttir ${ }^{\mathrm{e}}$ Rikke Krølner ${ }^{f}$ Lea Maes $^{\mathrm{g}}$ Carmen Pérez-Rodrigo ${ }^{\mathrm{h}}$ \\ Michael Sjöström ${ }^{a}$ Inga Thórsdóttir ${ }^{\mathrm{i}, \mathrm{j}}$ Knut-Inge Klepp ${ }^{\mathrm{k}}$

\begin{abstract}
${ }^{a}$ Department of Biosciences, Unit for Preventive Nutrition, Karolinska Institutet, Stockholm, Sweden;
${ }^{b}$ Institute for Nutritional Sciences, University of Vienna, Vienna, Austria; ${ }^{c}$ Department of Public Health, Erasmus University Medical Center Rotterdam, Rotterdam, The Netherlands; ${ }^{d}$ Faculty of Nutrition and Food Sciences, University of Porto, Porto, Portugal; ${ }^{e}$ Research Department of Human Nutrition, Royal Veterinary and Agricultural University, and ${ }^{\mathrm{f}}$ Department of Social Medicine, Institute of Public Health, Faculty of Health Sciences, University of Copenhagen, Copenhagen, Denmark; ${ }^{9}$ Department of Public Health, Ghent University, Ghent, Belgium; ' Community Nutrition Unit, Bilbao, Spain; 'Unit for Nutrition Research, Landspitali University Hospital, and ${ }^{\mathrm{j} D e p a r t m e n t}$ of Food Science, University of Iceland, Reykjavik, Iceland; ${ }^{\mathrm{k}}$ Department of Nutrition, Faculty of Medicine, University of Oslo, Oslo, Norway
\end{abstract}

\section{Key Words}

European schoolchildren $\cdot$ Fruit intake $\cdot$ Vegetable intake $\cdot 24$-Hour recall $\cdot$ Food frequency $\cdot$ Pro Children study

\begin{abstract}
Background/Aims: An adequate fruit and vegetable intake provides essential nutrients and nutritive compounds and is considered an important part of a healthy lifestyle. No simple instrument has been available for the assessment of fruit and vegetable intake as well as its determinants in school-aged children applicable in different European countries. Within the Pro Children Project, such an instrument has been developed. This paper describes the cross-sectional survey in 11-year-olds in 9 countries. Methods: The cross-sectional survey used nationally, and in 2 countries regionally, representative samples of schools and classes. The questionnaires, including a precoded 24-hour recall component and a food frequency part, were completed in the classroom. Data
\end{abstract}

were treated using common syntax files for portion sizes and for merging of vegetable types into four subgroups. Results: The results show that the fruit and vegetable intake in amounts and choice were highly diverse in the 9 participating countries. Vegetable intake was in general lower than fruit intake, boys consumed less fruit and vegetables than girls did. The highest total intake according to the 24-hour recall was found in Austria and Portugal, the lowest in Spain and Iceland. Conclusion: The fruit and vegetable intake in 11-year-old children was in all countries far from reaching population goals and foodbased dietary guidelines on national and international levels.

Copyright $(2005$ S. Karger AG, Basel

\section{Introduction}

For promotion of eating habits which are in line with recent food-based dietary guidelines [1-4], it is important to have valid and reliable, simple assessment tools avail-

\section{KARGER}

Fax +4161306 1234 E-Mailkarger@karger.ch www.karger.com
(C) 2005 S. Karger AG, Basel 0250-6807/05/0494-0236\$22.00/0

Accessible online at:

www.karger.com/anm
Agneta Yngve

Unit for Preventive Nutrition, Department of Biosciences, Novum

SE-141 57 Huddinge (Sweden)

Tel. +4686089209, +46705506557 (mobile), Fax +4686083350

E-Mail agneta.yngve@prevnut.ki.se 
Table 1. WHO population goal ${ }^{1}$ and national food-based dietary guidelines for fruit and vegetable intake

\begin{tabular}{|c|c|c|c|c|}
\hline \multirow[t]{2}{*}{ Country } & \multicolumn{3}{|c|}{ Recommendation } & \multirow[t]{2}{*}{ Comments } \\
\hline & fruit & vegetables & total & \\
\hline WHO Europe & & & $\geq 400 \mathrm{~g}$ & tubers excluded; all age groups included \\
\hline Austria & $250 \mathrm{~g}$ & $250 \mathrm{~g}$ & 5 times/day & potatoes excluded; for 10 - to 12 -year-olds \\
\hline Belgium & $1-3$ portions & $300 \mathrm{~g}$ & & juice and potatoes excluded; from 6 years and onwards \\
\hline Denmark & 3 portions & 3 portions & $600 \mathrm{~g}$ & $\begin{array}{l}\text { potatoes excluded, juice included as maximum one portion; for } \\
\text { children from } 10 \text { years and above and adults; portions used for } \\
\text { evaluation of intake }\end{array}$ \\
\hline Iceland & $>200 \mathrm{~g}$ & $>200 \mathrm{~g}$ & $500 \mathrm{~g}$ & potatoes excluded, fruit juice included in total; all age groups \\
\hline Netherlands & $\begin{array}{l}2 \text { pieces of } \\
\text { fruit }\end{array}$ & $150 \mathrm{~g}$ & & $\begin{array}{l}\text { potatoes excluded; one piece of fruit can be taken as juice; a } \\
\text { piece equals approx. } 125 \mathrm{~g} \text { of fruit, or one apple }\end{array}$ \\
\hline Norway & 2 portions & 3 portions & $750 \mathrm{~g}$ & $\begin{array}{l}\text { potatoes and fruit juice included; for adults; same number of } \\
\text { portions for children although smaller }\end{array}$ \\
\hline Portugal & $3-5$ portions & $3-5$ portions & & $\begin{array}{l}\text { potatoes excluded; portions used for evaluation of energy/calo- } \\
\text { ries intake: } 3-5 \text { portions for } 2,200 \mathrm{kcal} \text { - general population; } 5 \\
\text { for }>3,000 \mathrm{kcal}\end{array}$ \\
\hline Spain & 3 portions & 2 portions & $\geq 400 \mathrm{~g}$ & $\begin{array}{l}\text { potatoes and fruit juice excluded; same number of portions for } \\
\text { children although smaller; portions used for evaluation of intake }\end{array}$ \\
\hline Sweden & & & $\geq 400-500 \mathrm{~g}$ & $\begin{array}{l}\text { potatoes excluded, fruit juice counted as maximum } 100 \mathrm{~g} ; 400 \mathrm{~g} \\
\text { for children up to } 10 ; 500 \text { for all }>10 \text { years of age }\end{array}$ \\
\hline
\end{tabular}

\footnotetext{
${ }^{1}$ Population intake goals represent the population average intake that is judged to be consistent with the maintenance of health in a population.
}

able. No such assessment tool exists in Europe for use in cross-national comparisons. During the last decades, an increasing amount of attention has been paid to the importance of a high fruit and vegetable intake as an essential part of a healthy lifestyle $[1,2]$. The importance of fruit and vegetables for providing essential nutrients such as folate, vitamin $C$ and $\beta$-carotene has been emphasized by several reports [1-5], as well as for providing antioxidants of nonvitamin nature and so-called phytoestrogens [1-5]. A number of international recommendations $[1,3,4]$ and population targets [2] have been published regarding the desirable level of consumption of fruit and vegetables for adults. A summary of the range reported in the national food-based dietary guidelines for fruit and vegetable intake in the European region is 'more than 400-600 g per day' [6], where the range stands for the variability between countries. The WHO population goal [3] for fruit and vegetable intake is $400 \mathrm{~g}$ per day. National food-based dietary guidelines for adults can be found in all investigated countries [3,7-15], specific guidelines for children exist in some of the investigated countries [3, 7, 10-13, 15-17] (table 1). The guidelines in some cases include suggestions for how they can be used to evaluate intakes.

Fruit and vegetable intake of children has not been extensively monitored on the European level, but has been studied in some national [18-20] surveys. There have been attempts to quantify the intake of individual members of the household from household budget surveys [21], thereby providing possibilities for identifying the fruit and vegetable intake of children. The Health Behaviour in School-Aged Children Study [22] has collected data on fruit and vegetable intake through a simple food frequency questionnaire since 1985 . A common protocol for a slightly more sophisticated method of investigating the fruit and vegetable intake in schoolchildren has been missing in the European context.

\section{The Pro Children Project}

The Pro Children cross-sectional survey was designed to provide information on actual levels of fruit and veg- 
Table 2. Sample selection, response rates, dropout and data cleaning description by country

\begin{tabular}{|c|c|c|c|c|c|c|c|c|c|c|}
\hline \multirow[t]{2}{*}{ Country } & \multirow{2}{*}{$\begin{array}{l}\text { Partici- } \\
\text { pants }\end{array}$} & \multicolumn{2}{|c|}{ Response rate } & \multicolumn{2}{|c|}{ Dropout rate } & \multicolumn{2}{|c|}{ Data entry } & \multicolumn{3}{|c|}{ Data included in the analyses } \\
\hline & & $\mathrm{n}$ & $\%$ of part & $\mathrm{n}$ & $\%$ of part & $\mathrm{n}$ & $\%$ of part & $\mathrm{n}$ & $\%$ of part & $\%$ of data entry \\
\hline Norway & 1,347 & 1,205 & 89.5 & 9 & 0.7 & 1,196 & 88.8 & 1,157 & 85.9 & 96.7 \\
\hline Spain & 1,410 & 1,335 & 94.7 & 22 & 1.6 & 1,313 & 93.1 & 1,289 & 91.4 & 98.2 \\
\hline Iceland & 1,392 & 1,235 & 88.7 & 39 & 2.8 & 1,196 & 85.9 & 1,176 & 84.5 & 98.3 \\
\hline Denmark & 2,111 & 1,942 & 92.0 & 23 & 1.1 & 1,919 & 90.9 & 1,859 & 88.1 & 96.9 \\
\hline Portugal & 2,535 & 2,494 & 98.4 & 360 & 14.2 & 2,134 & 84.2 & 2,118 & 83.6 & 99.3 \\
\hline Austria & 1,857 & 1,769 & 95.3 & 77 & 4.1 & 1,692 & 91.1 & 1,656 & 89.1 & 97.9 \\
\hline Netherlands & 1,396 & 1,113 & 79.7 & 8 & 0.6 & 1,105 & 79.2 & 1,096 & 78.5 & 99.2 \\
\hline Sweden & 1,752 & 1,476 & 84.2 & 69 & 3.9 & 1,407 & 80.3 & 1,364 & 77.9 & 96.9 \\
\hline Belgium & 1,604 & 1,355 & 84.5 & 12 & 0.7 & 1,343 & 83.7 & 1,322 & 82.4 & 98.4 \\
\hline Total & 15,404 & 13,924 & 90.4 & 619 & 4.0 & 13,305 & 86.4 & 13,037 & 84.6 & 98.0 \\
\hline
\end{tabular}

part $=$ Participants

etable intake among European schoolchildren and their parents as well as the determinants of such consumption patterns. The Pro Children cross-sectional survey constitutes the first ever cross-national comparison of fruit and vegetable intake performed in children, while including determinants (cultural, socioeconomic, and sociocognitive factors). The large variation seen in eating habits across Europe, including practices related to the fruit and vegetable intake, made it particularly important to conduct such a study.

The main objective of the present paper was to describe the results of the Pro Children cross-sectional survey with regard to the total fruit and vegetable intake and frequency of consumption in children in all the participating countries, compared to relevant dietary guidelines.

\section{Method}

The cross-sectional survey of the schoolchildren and their parents was conducted in all 9 countries during October to December 2003. Schools constituted the sampling unit, and from each country samples of at least 20 schools and a minimum of 1,300 eligible children were included. The student sample size was seen as sufficient to allow for the planned within-country comparisons (gender, socioeconomic status and urban-rural differences) and take the school component of the variance into account. The target group was children born in 1992. Nationally statistically representative samples of schools were drawn in each country with the exception of Austria and Belgium. For Austria, the sample is statistically representative of the eastern region (population of approximately 4 million; $42 \%$ of total population). For Belgium, the sample is statistically representative of Flanders (the Dutch-speaking north-western half of the country, population of approximately 6 million, $58 \%$ of total population). The response rates, dropouts and incomplete questionnaires rejected during data cleaning are described in table 2 , while the age and gender distribution of the final sample is described in table 3 . Only $1.7 \%$ of the 24 -hour recall ( 0.6 girls $/ 1.1$ boys) and $1.9 \%$ of the food frequency ( 0.9 girls/ 1.0 boys) questionnaires were excluded from the analysis due to incomplete answers in the dietary intake part of the questionnaire.

\section{The Instrument}

A comprehensive survey instrument assessing fruit and vegetable intake and psychosocial factors associated with these consumption patterns was developed for both pupils and their parents. The instruments were originally developed in English prior to translation into the relevant languages within each participating country. These national versions were then back-translated into English by language-proficient individuals not involved in the development of the instruments.

The dietary questionnaire comprises two sections: a precoded 24-hour recall component asking in detail about yesterday's fruit and vegetable intake, and a food frequency part with 5 questions on usual fruit and vegetable intake. The 24-hour recall component was used for measuring group mean intake and for specifying the type of fruits and vegetables eaten, whereas the food frequency part was used for ranking subjects according to their usual intake. The instrument is further described by Haraldsdottir et al. [23]. Multiple pilot tests, including reliability and validity testing, were conducted in a number of countries before the final instrument was decided upon [23]. Based on formal testing of the child instruments in Belgium, Denmark, Iceland, Norway and Portugal, it was concluded that the questionnaire instrument was valid and reliable in giving national group means of fruit and vegetable intake among 11 -year-old children as well as ranking them by intake.

\section{The Procedure}

The headmasters of the schools were approached about their willingness to participate, and the class teachers were asked to col- 
Table 3. Age and gender distribution of the final sample by country and total

\begin{tabular}{|c|c|c|c|c|c|c|c|c|c|c|}
\hline \multirow[t]{2}{*}{ Country } & \multicolumn{3}{|l|}{ Total } & \multicolumn{3}{|c|}{ Girls } & \multicolumn{4}{|l|}{ Boys } \\
\hline & $\mathrm{n}$ & age & SD & $\mathrm{n}$ & age & SD & $\mathrm{n}$ & age & SD & $\%$ boys \\
\hline Austria & 1,656 & 11.0 & 0.59 & 871 & 11.0 & 0.59 & 785 & 11.1 & 0.60 & 47.4 \\
\hline Belgium & 1,322 & 11.5 & 0.46 & 606 & 11.5 & 0.46 & 716 & 11.5 & 0.46 & 54.2 \\
\hline Denmark & 1,859 & 11.4 & 0.38 & 918 & 11.3 & 0.35 & 941 & 11.4 & 0.39 & 50.6 \\
\hline Iceland & 1,176 & 11.3 & 0.33 & 562 & 11.3 & 0.34 & 614 & 11.3 & 0.31 & 52.2 \\
\hline Netherlands & 1,096 & 11.7 & 0.46 & 590 & 11.7 & 0.44 & 506 & 11.8 & 0.48 & 46.2 \\
\hline Norway & 1,157 & 11.3 & 0.32 & 569 & 11.3 & 0.32 & 588 & 11.3 & 0.31 & 50.8 \\
\hline Portugal & 2,118 & 11.5 & 0.45 & 1,115 & 11.5 & 0.43 & 1,003 & 11.5 & 0.47 & 0.47 \\
\hline Spain & 1,289 & 11.4 & 0.44 & 599 & 11.4 & 0.41 & 690 & 11.4 & 0.46 & 53.5 \\
\hline Sweden & 1,364 & 11.4 & 0.47 & 687 & 11.4 & 0.47 & 677 & 11.4 & 0.46 & 49.6 \\
\hline Total & 13,037 & 11.4 & 0.48 & 6,517 & 11.3 & 0.47 & 6,520 & 11.4 & 0.48 & 50.0 \\
\hline
\end{tabular}

lect the data using standardized instructions. The data for the children's intake were collected directly in the classroom using the validated instrument. Data were entered at the national centers, according to a standardized protocol, prior to submission to the joint Data Management Centre at the University of Vienna, where data processing and quality control has taken place.

\section{Data Treatment}

The results from the 24-hour recalls regarding vegetables were merged into four subgroups, i.e. salad, raw vegetables, cooked vegetables and soup vegetables, in order to provide useful information for the design of interventions. The results from the food frequency questionnaire were converted to 'once a day or more' regarding frequency of total fruit and vegetable intake. Portion sizes were corrected for differences in standard servings between countries, in particular for cucumber and carrots (due to different slicing habits for pieces or slices). A maximum number of portions consumed per meal was determined for each fruit and vegetable item and intakes were adjusted using a standardized script. The results were tested for agerelated differences. As no such differences could be identified, the results are presented only according to gender and country.

\section{Research Clearance}

The cross-sectional survey involves children (9-13 years of age) and their parents (healthy volunteers). Self-administered questionnaires are the only research instruments used. Parental written consent was obtained prior to including the children in the cross-sectional survey. Furthermore, research clearance was obtained from research ethics committees in all countries where this was regulated for this kind of noninvasive study.

\section{Data Analysis}

Data analysis was conducted using the program software Statistical Package for Social Sciences 12.0 (SPSS). For age and gender differences, statistical significance was established as $p<0.05$. Nonparametric Mann-Whitney U tests corrected with Shaffer were used, due to the absence of normal distribution of consumption data even after logarithmic transformation.

Fruit and Vegetable Intake of 11-Year-Old Europeans

\section{Results}

\section{4-Hour Recall}

Fruit, fruit juice, vegetable, as well as added fruit and vegetable intake are presented in table $4 a-d$. Girls had a significantly higher fruit, vegetable and total fruit and vegetable intake than boys $(\mathrm{p}<0.000)$ and a slightly higher fruit juice intake, though not significant $(p=0.098)$. A large variation in consumption was found between the countries. The highest overall fruit intakes were found in Austria, Denmark and Portugal (171, 157 and $153 \mathrm{~g}$ ). Fruit intakes were lowest in Iceland and Spain (90 and $118 \mathrm{~g}$ ). Children in Portugal, Sweden and Belgium showed the highest overall vegetable intakes in this study (mean 111,109 and $105 \mathrm{~g}$ ). The countries with the lowest vegetable intakes were Iceland and Spain (mean 54 and $58 \mathrm{~g}$ ). The highest overall fruit and vegetable intakes were found in Austria and Portugal (265 and 264 g), while the lowest intakes were found in Iceland and Spain (143 and $176 \mathrm{~g}$ ). The highest juice intakes were found in Austria and the Netherlands (360 and $267 \mathrm{~g}$ ), the lowest in Portugal and Denmark (142 and $143 \mathrm{~g}$ ).

Figure 1 presents the average fruit intake in grams per day per country. Figure 2 shows vegetable intake in grams/day per country indicating the type of vegetables eaten. Raw vegetables were consumed much more in the northern countries. In Portugal and Spain, the main intake of vegetables came from vegetable soup.

\section{Food Frequency Questionnaire}

The food frequency data are presented in figures 3 and 4. The percentage of children choosing the alternatives

Ann Nutr Metab 2005;49:236-245 
Table 4. The 24-hour recall ( $\mathrm{P}=$ percentile)

a Fruit intake (g)

\begin{tabular}{|c|c|c|c|c|c|c|c|c|c|c|}
\hline \multirow[t]{2}{*}{ Country } & \multicolumn{6}{|l|}{ Total } & \multicolumn{2}{|l|}{ Girls } & \multicolumn{2}{|l|}{ Boys } \\
\hline & mean & $95 \% \mathrm{CI}$ & median & $\mathrm{P} 25$ & P75 & P90 & mean & median & mean & median \\
\hline Austria & 171 & $163-179$ & 150 & 0 & 250 & 400 & 171 & 125 & 171 & 150 \\
\hline Belgium & 137 & $130-145$ & 100 & 0 & 200 & 300 & 142 & 100 & 133 & 100 \\
\hline Denmark & 157 & $150-164$ & 100 & 0 & 200 & 400 & 168 & 150 & 146 & 100 \\
\hline Iceland & 90 & 83-96 & 50 & 0 & 100 & 250 & 87 & 50 & 93 & 50 \\
\hline Netherlands & 134 & $126-142$ & 100 & 0 & 200 & 300 & 142 & 100 & 125 & 100 \\
\hline Norway & 149 & $140-158$ & 100 & 0 & 200 & 375 & 157 & 100 & 141 & 100 \\
\hline Portugal & 153 & $147-158$ & 150 & 50 & 200 & 300 & 152 & 150 & 153 & 125 \\
\hline Spain & 118 & $111-125$ & 100 & 0 & 200 & 300 & 117 & 100 & 118 & 100 \\
\hline Sweden & 129 & $122-136$ & 100 & 0 & 200 & 300 & 134 & 100 & 125 & 100 \\
\hline Total & 141 & $138-143$ & 100 & 0 & 200 & 300 & 144 & 100 & 137 & 100 \\
\hline
\end{tabular}

b Juice intake (g)

\begin{tabular}{lrrrrrrrrrr}
\hline Austria & 360 & $343-378$ & 300 & 0 & 600 & 800 & 348 & 300 & 375 & 400 \\
Belgium & 225 & $210-240$ & 200 & 0 & 400 & 600 & 215 & 200 & 234 & 200 \\
Denmark & 143 & $133-154$ & 0 & 0 & 200 & 400 & 144 & 0 & 142 \\
Iceland & 211 & $197-225$ & 200 & 0 & 400 & 600 & 200 & 200 & 221 \\
Netherlands & 267 & $250-284$ & 200 & 0 & 400 & 600 & 287 & 200 & 200 \\
Norway & 195 & $179-211$ & 0 & 0 & 400 & 600 & 207 & 100 & 184 & 200 \\
Portugal & 142 & $133-150$ & 0 & 0 & 200 & 400 & 135 & 0 & 150 & 0 \\
Spain & 213 & $202-225$ & 200 & 0 & 400 & 500 & 212 & 200 & 214 & 200 \\
Sweden & 197 & $182-212$ & 0 & 0 & 400 & 600 & 186 & 0 & 209 \\
\hline Total & 213 & $208-217$ & 200 & 0 & 400 & 600 & 209 & 200 & 215 & 200 \\
\hline
\end{tabular}

c Vegetable intake $(\mathrm{g})$

\begin{tabular}{lrcrrrrrrrr}
\hline Austria & 94 & $89-99$ & 60 & 0 & 140 & 240 & 99 & 60 & 88 & 60 \\
Belgium & 105 & $100-110$ & 80 & 30 & 150 & 235 & 101 & 80 & 108 & 80 \\
Denmark & 84 & $79-89$ & 40 & 0 & 125 & 231 & 92 & 60 & 76 \\
Iceland & 54 & $49-59$ & 10 & 0 & 70 & 165 & 57 & 30 & 50 \\
Netherlands & 70 & $65-75$ & 60 & 0 & 100 & 160 & 73 & 60 & 67 & 60 \\
Norway & 67 & $62-73$ & 30 & 0 & 105 & 195 & 75 & 40 & 60 & 10 \\
Portugal & 111 & $107-115$ & 80 & 30 & 160 & 250 & 112 & 90 & 110 & 80 \\
Spain & 58 & $54-62$ & 40 & 0 & 80 & 160 & 56 & 40 & 60 & 40 \\
Sweden & 109 & $103-115$ & 75 & 20 & 155 & 265 & 118 & 80 & 100 & 65 \\
\hline Total & 86 & $85-88$ & 60 & 0 & 130 & 220 & 90 & 60 & 83 \\
\hline
\end{tabular}

d Fruit plus vegetable intake (g)

\begin{tabular}{llllrllllll}
\hline Austria & 265 & $254-275$ & 210 & 100 & 390 & 590 & 269 & 220 & 259 & 200 \\
Belgium & 242 & $232-252$ & 200 & 100 & 340 & 500 & 243 & 210 & 242 & 200 \\
Denmark & 241 & $231-250$ & 200 & 80 & 350 & 535 & 260 & 215 & 222 & 180 \\
Iceland & 143 & $134-153$ & 100 & 0 & 200 & 350 & 144 & 100 & 143 \\
Netherlands & 204 & $194-214$ & 165 & 100 & 284 & 430 & 214 & 180 & 100 \\
Norway & 216 & $204-228$ & 160 & 60 & 315 & 505 & 232 & 200 & 201 \\
Portugal & 264 & $256-271$ & 240 & 130 & 361 & 500 & 264 & 240 & 143 \\
Spain & 176 & $168-185$ & 145 & 50 & 250 & 390 & 174 & 150 & 179 \\
Sweden & 238 & $228-249$ & 200 & 93 & 340 & 500 & 251 & 225 & 225 & 140 \\
Total & 227 & $224-230$ & 190 & 80 & 330 & 500 & 235 & 200 & 219 \\
\hline
\end{tabular}


Fig. 1. Mean consumption of fruit (g/day).

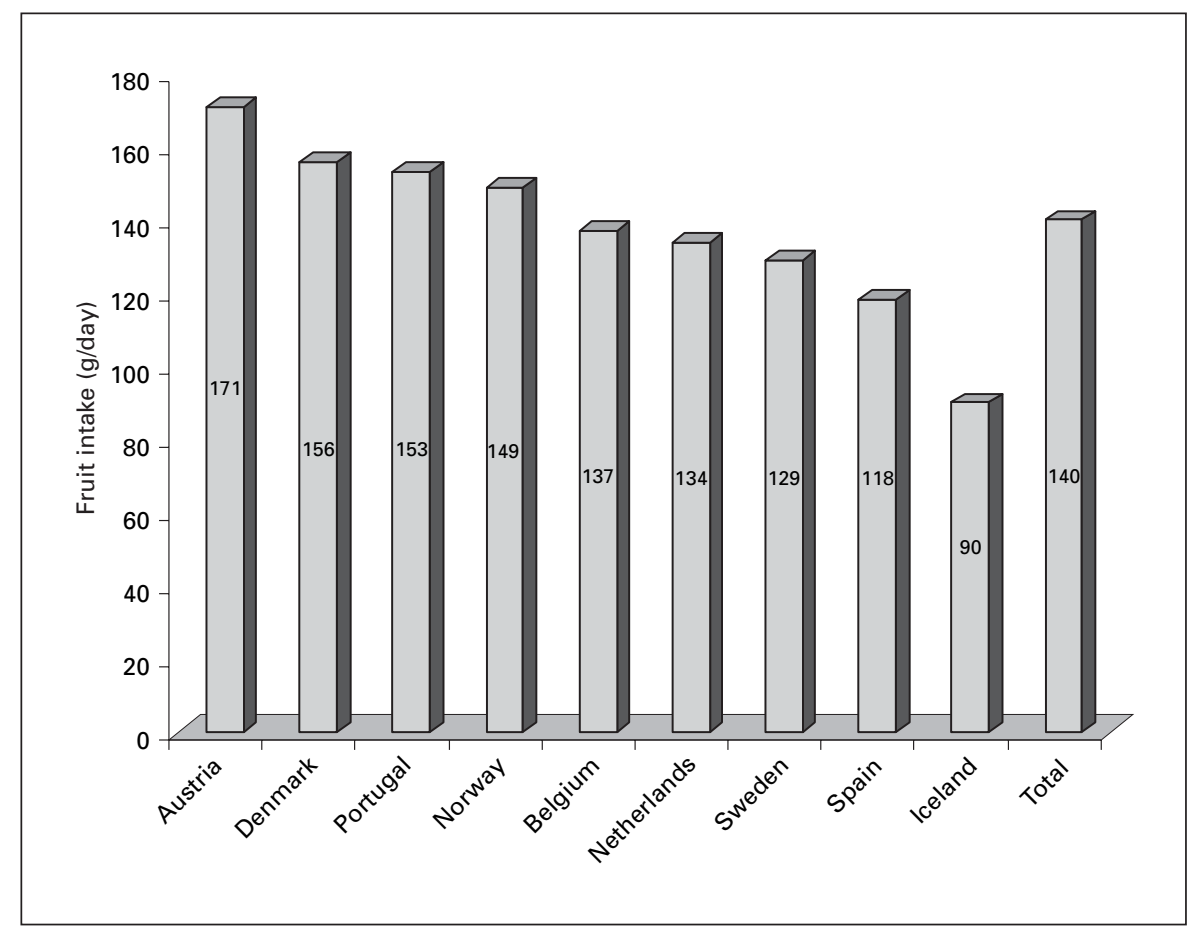

Fig. 2. Mean consumption of vegetables,

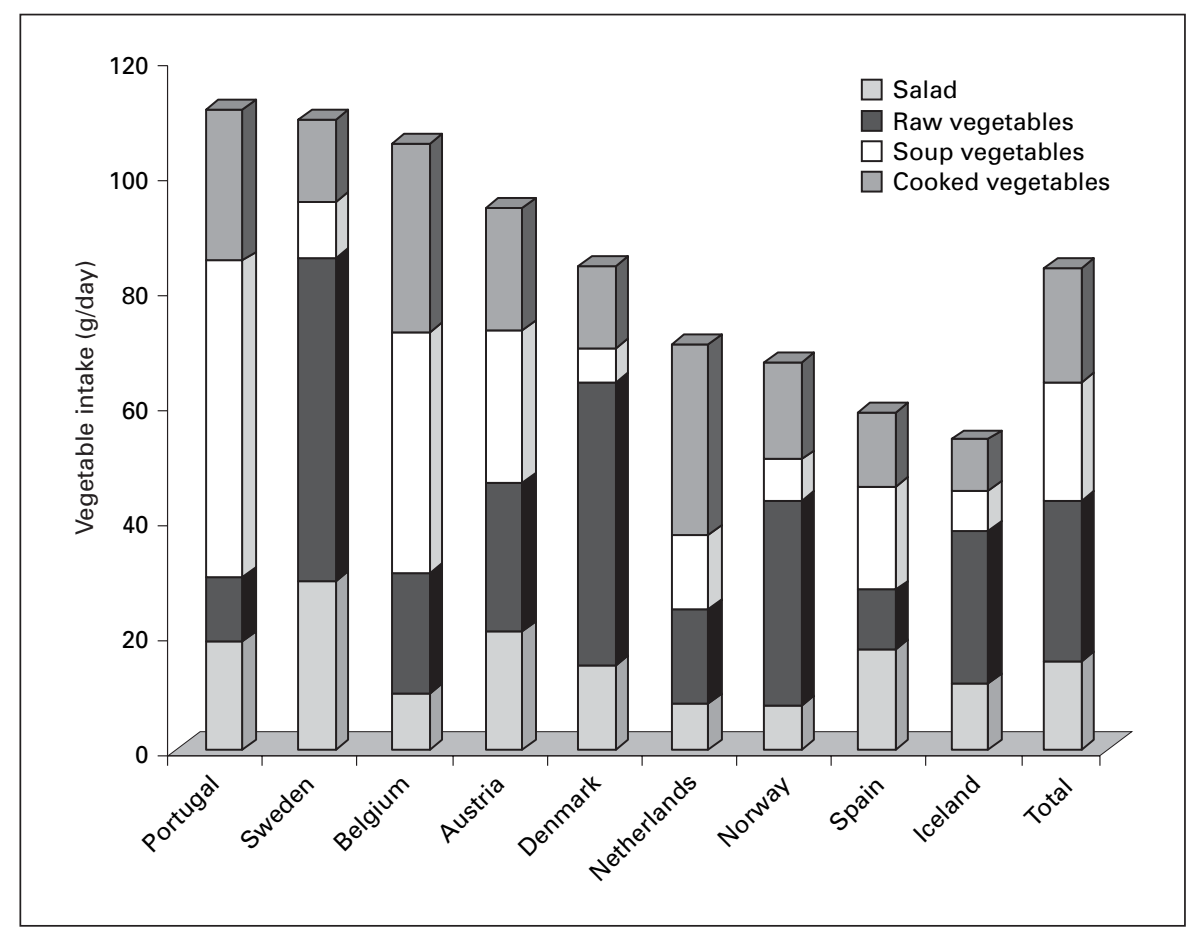

once every day, twice every day, more than twice every day for both fruit and vegetable is shown. Less than half of all the investigated children indicated that they eat fruit (48\%) or vegetable (45\%) every day.

Fruit and Vegetable Intake of 11-Year-Old Europeans

\section{Discussion}

Among the 9 European countries participating in this cross-sectional survey, a diverse and complicated picture of fruit and vegetable intake emerged. Children in all

Ann Nutr Metab 2005;49:236-245 
Fig. 3. Frequency of intake of fruit, $\geq 1$ time per day.
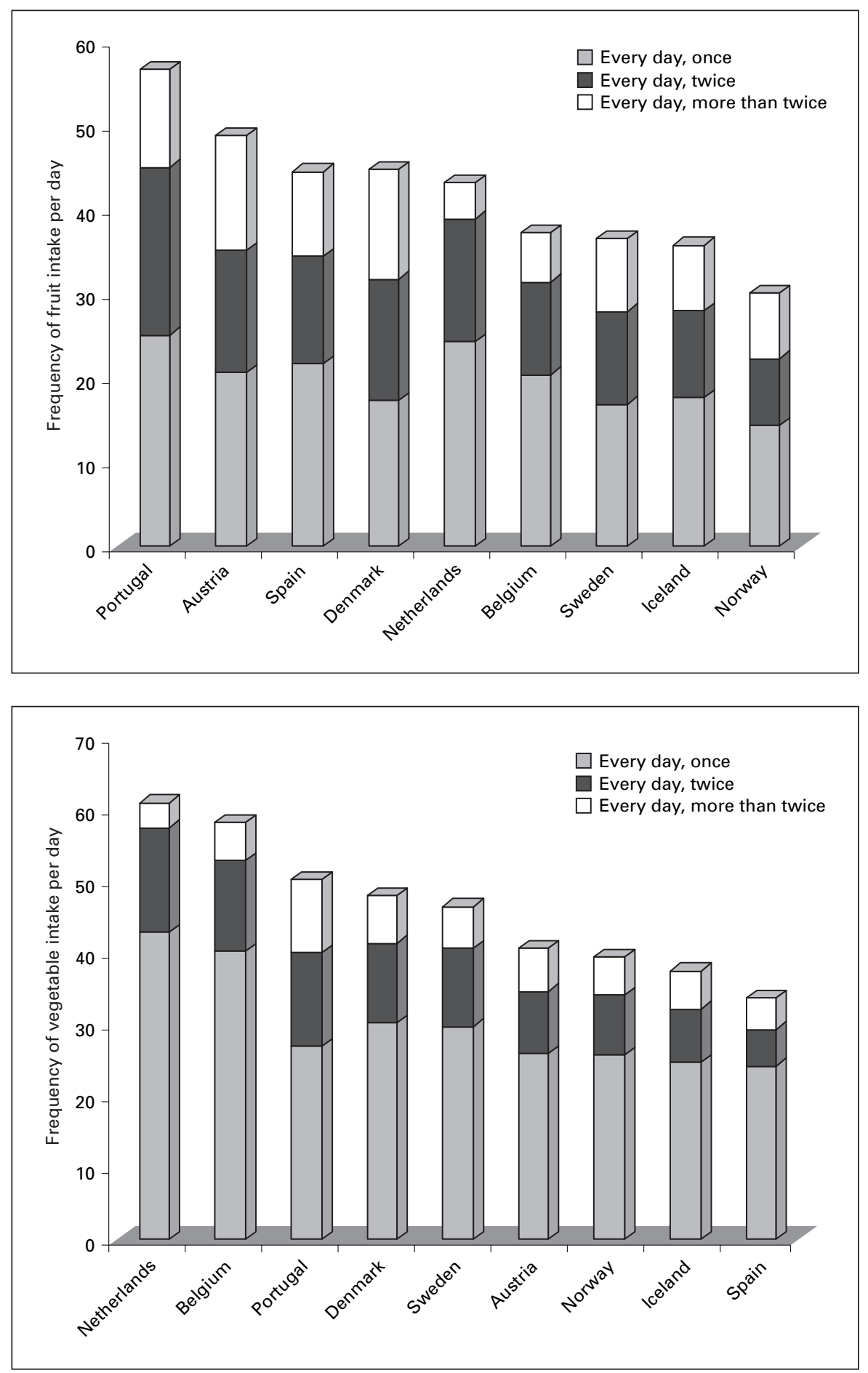

Fig. 4. Frequency of intake of vegetables, $\geq 1$ time per day.

countries showed relatively low intakes of both fruit and vegetables with consistently lower intakes of vegetables. Boys had in general a lower fruit and vegetable intake than girls. There was no clear north-south gradient, except for the type of vegetables eaten (raw vegetables, cooked vegetables and vegetable soup). The higher intake of raw vegetables in the northern countries might reflect different preferences, but could also have been due to culturally dependent factors related to food preparation and availability. 
The response rates were overall unusually high, probably due to the use of schools and classes as sampling units. Due to the school-based survey, respondent bias (overrepresentation of healthy, well-educated subjects) was probably lower than in other types of studies. Because of the statistically representative samples in all countries except for Belgium and Austria, the results should be representative for the countries, and for Belgium and Austria for the chosen regions. Comparisons between the countries could however present some problems, due to differences in food culture and perception of portion sizes.

The main limitation of the 24-hour recall in this precoded instrument was that intakes were recorded for one weekday only and therefore did not reflect usual intake. The food frequency questionnaire should to some extent have corrected for this and in comparison, the ranking of countries based on actual intake (24-hour recall) fits rather nicely with the ranking of usual intake (food frequency questionnaire). In Spain, we could, however, see that the ranking for usual intake seemed higher than the actual intake for fruit, and in the Netherlands the ranking for usual intake was higher for vegetables than the one for actual intake. Group averages of weekday intakes were considered relatively reliable due to the narrow age range and such large samples in each country.

Another problem with the instruments was the portion size estimation for carrots and cucumber that was performed by the Pro Children consortium, where the ways of serving these vegetables turned out to be diverse between countries (e.g. sticks of different sizes, thick or thin slices). Also, as was shown in focus groups [24], children in Belgium had problems distinguishing fruit juice from lemonades and other fruit-based drinks, which is why the data on fruit juice should be interpreted with caution.

Fruit juice intake seemed high in some countries, and may have contributed substantially to the intake of vitamin $\mathrm{C}$ and folate. Another problem with the survey results was the fact that different vegetables have very different contents of active compounds of nutrients and other potentially nutritionally important components.

In adding up intakes of different kinds of fruits and vegetables to total intake levels, we therefore neglected possibly relevant differences within the fruit and vegetable food groups. We did not include potatoes in the analysis, which might provide substantial amounts of vitamin $\mathrm{C}$ in countries where potato consumption is high. Another problem was the season when the data were collected. October and November are in many countries, except for Spain, the period when nationally or locally grown fruit, berries and vegetables are available in vast amounts. This could mean that data for fruit and vegetable intake collected at other times of the year could be even lower, or in the case of Spain that fruit and vegetable intake would be higher if collected at another time of the year.

Generally, the results of the present study were in line with the results from earlier studies on fruit and vegetable intake in the participating countries $[9,19,25-30]$ when taking the differences in methodology and year of survey into account. The results of the present study for both fruit and vegetable intake frequency also show roughly the same ranking of countries as the Health Behaviour in School-Aged Children Study [22]. However, data on availability of fruits and vegetables [31, 32] show a northsouth gradient, where the southernmost countries had the highest availability; a finding that was not reflected in the present results.

The WHO population goal [3] for consumption of fruit and vegetables (table 1) is $400 \mathrm{~g}$ per day. It does not specify whether fruit juice should be included. The WHO population goal represents the population average that is judged to be consistent with the maintenance of health. No clear guidelines on how to interpret the population goal for intake evaluation purposes could be identified. Our analyses indicate that average intakes of children in almost all countries exceeded the population goal of $400 \mathrm{~g}$ when our data on fruit juice were included. However, we showed earlier [24] that children of this age had problems distinguishing fruit juice from other fruit drinks or lemonades. After exclusion of juice intake, the results showed that mean intakes of fruit and vegetables in all countries were lower than the WHO population goal. Children in Austria and Portugal, with the highest intakes of fruit and vegetables, both reached a mean intake of about $264 \mathrm{~g}$ per day.

No guidelines for how to interpret population goals for this specific age group were identified either. Possibly, children of this age group should end up somewhere in the lower end of the range compared with the range of intake for the whole population. Due to this problem, it was even more difficult to judge to which extent the population of children in this study achieved the WHO population goal.

An attempt was made to use a British example [33] of identifying compliers and noncompliers of the WHO population goal of $400 \mathrm{~g}$. This was done by ranking the sum of vegetable and fruit intake and selecting a cutoff point when the group mean reached $400 \mathrm{~g}$. The cutoff applied in the total group was $210 \mathrm{~g}$, depending on the distribution of intake. In the total sample, the resulting per- 
Table 5. Percentage of 11-year-old children with fruit plus vegetable intake $\geq 400 \mathrm{~g}$, by gender and country

\begin{tabular}{|c|c|c|c|c|c|c|}
\hline \multirow[t]{2}{*}{ Country } & \multicolumn{2}{|c|}{ Total } & \multicolumn{2}{|c|}{ Girls } & \multicolumn{2}{|c|}{ Boys } \\
\hline & $\mathrm{n}$ & $\%$ & $\mathrm{n}$ & $\%$ & $\mathrm{n}$ & $\%$ \\
\hline Austria & 400 & 24.1 & 212 & 24.3 & 188 & 23.9 \\
\hline Belgium & 253 & 19.1 & 108 & 17.8 & 145 & 20.3 \\
\hline Denmark & 394 & 21.2 & 218 & 23.7 & 176 & 18.7 \\
\hline Iceland & 92 & 7.8 & 36 & 6.4 & 56 & 9.1 \\
\hline Netherlands & 130 & 11.9 & 77 & 13.1 & 53 & 10.5 \\
\hline Norway & 202 & 17.5 & 109 & 19.2 & 93 & 15.8 \\
\hline Portugal & 453 & 21.4 & 227 & 20.4 & 226 & 22.5 \\
\hline Spain & 125 & 9.7 & 45 & 7.5 & 80 & 11.6 \\
\hline Sweden & 250 & 18.3 & 136 & 19.7 & 114 & 16.8 \\
\hline Total & 2,299 & 17.6 & 1,168 & 17.9 & 1,131 & 17.3 \\
\hline
\end{tabular}

centage of compliers (which should be $100 \%$ if the population goal was achieved) was $44.5 \%$. Among the compliers, there were more girls than boys in all countries except for Spain. If, on the other hand, the $400 \mathrm{~g}$ population goal is used as a cutoff for fruit and vegetable intake, we can see that the percentage of 11-year-olds in the 9 countries that eat $400 \mathrm{~g}$ of fruits and vegetables per day varies between 6.4 and $24.3 \%$, depending on gender and country (table 5).

National recommendations were in most cases higher than the WHO population goal (table 1). In some countries, fruit juice without limitation was included in the recommendation, while other countries allowed the inclusion of one portion of fruit juice per day, interpreted as $100 \mathrm{~g}$. Yet other countries did not include fruit juice at all. In all countries, except for Norway, potatoes were excluded from the recommendations. Some countries used the same recommendations for adults and children. The recommendations sometimes included guidelines for interpretation of survey results; Spain, Denmark and Portugal specified that portions were supposed to be used for evaluation of intake. When taking all these factors into account, the average intake in all countries failed to reach the own nationally recommended levels in this study.

For those countries which used portions for evaluating intake, 6.0 and $5.8 \%$ of girls and boys in Denmark, 19.5 and $13.3 \%$ in Norway, 23.2 and $22.2 \%$ in Portugal and 0.8 and $1.2 \%$ in Spain reached the recommended number of portions for fruit and vegetables. Comparison of the Norwegian data with national recommendations was however difficult as potato intake was not measured in this study.
The Dutch and Belgian recommendations are expressed both in grams (for vegetables) and portions (for fruit). For the Netherlands 7.8 and 5.7\%, and for Belgium 14.0 and $13.3 \%$ of girls and boys, respectively, reached both recommendations for fruit and vegetables.

For Austria 6.4 and $7.6 \%$, for Iceland 3.4 and $4.6 \%$ and for Sweden 15.7 and $13.3 \%$ of girls and boys reached the recommended intakes, which ranged from 400 to $600 \mathrm{~g}$. According to the National Food Administration in Sweden, the recommendation for fruit and vegetables for Sweden $(1 / 2 \mathrm{~kg})$ should be seen as a population goal, which means that half of the whole population should reach the recommendation.

In the above calculations, fruit juice was not counted at all. This could mean that the results were too pessimistic in many cases, since fruit juice could have contributed to a higher intake of for example folate and vitamin $\mathrm{C}$ than indicated by the data on fruit and vegetables.

\section{Conclusions}

The average fruit and vegetable intake did not reach WHO population goals or national recommendations in any country when fruit juice was excluded. The fruit and vegetable intake was highly variable across Europe, for total amounts and types of vegetables eaten. Vegetable intake was clearly lower than fruit intake. A large proportion of the investigated group stated a frequency of intake which was less than once a day of fruit and vegetables, respectively.

The future analysis of determinants for fruit and vegetable intake in the Pro Children cross-sectional survey will be of great importance for identifying ways to correct the inadequate intakes that were identified in this analysis.

We can also conclude that there were difficulties in the interpretation of the WHO population goal, since no clear guidelines seemed to exist regarding (1) the inclusion or exclusion of fruit juice and (2) interpretation within selected age groups. Moreover, national recommendations are highly variable and sometimes difficult to interpret.

\section{Acknowledgements}

This study is being carried out with financial support from the Commission of the European Communities, specific RTD program 'Quality of Life and Management of Living Resources', QLK1- 
2001-00547 'Promoting and Sustaining Health through Increased Vegetable and Fruit Consumption among European Schoolchildren' (Pro Children). The study does not necessarily reflect the Commission's views and in no way anticipates its future policy in this area. Special thanks to all the teachers, headmasters and above all, the children who took the time to participate in this survey, to the staff and students from all 9 participating countries who have collected and entered the data, to Professor Emeritus Leif Hambraeus who advised on the interpretation of results and finally to Emma Patterson who checked the English and gave good advice.

\section{References}

1 World Health Organization: Global Strategy on Diet, Physical Activity and Health. Geneva, World Health Organization, 2004.

2 Nutrition and diet for healthy lifestyles in Europe: science and policy implications. Proceedings of the European Conference, May 18-20, 2000, Crete, Greece. Public Health Nutr 2001; 4:337-434.

3 Diet, nutrition and the prevention of chronic diseases. World Health Organ Tech Rep Ser 2003;916:i-viii, 1-149, backcover.

4 American Institute for Cancer Research: Food, Nutrition and the Prevention of Cancer: A Global Perspective. Washington, American Institute for Cancer Research, 1997.

5 Klerk M, Jansen CJF, van’t Veer P, Kok FJ: Fruits and Vegetables in Chronic Disease Prevention. Wageningen, Division of Human Nutrition and Epidemiology, Wageningen Agricultural University, 1995.

6 World Health Organization: Food-Based Dietary Guidelines in WHO European Member States. Copenhagen, WHO Regional Office for Europe, 2002.

7 Trolle E, Fagt S, Ovesen L: Fruit and vegetables, recommendations for intake; in: Danish Veterinary and Food Administration C. Copenhagen, Quickly Tryk A/S, 1998.

8 Deutsche Gesellschaft für Ernährung, Österreichische Gesellschaft für Ernährung, Schweizerische Gesellschaft für Ernährungsforschung, Schweizerische Vereinigung für Ernährung: Referenzwerte für die Nährstoffzufuhr, ed 1, corr reprint 2. Frankfurt, Umschau Braus GmbH, 2001.

9 Steingrimsdottir L, Thorgeirsdottir H, Olafsdottir AS: The Diet of Icelanders. Dietary Survey of the Icelandic Nutrition Council 2002: Main Findings. Reykjavik, Icelandic Nutrition Council, 2003.

10 Blomhoff R, Lande B, Ose T: Recommendations for Increased Intake of Fruit and Vegetables. Oslo, National Nutrition Council, 1996.

11 Zo eet Nederland. Den Haag, Voedingscentrum, 1998.
12 A nova roda dos alimentos. Uma guia para escolha alimentar diaria! Coma bem, viva melhor. Porto, Garra, Faculdade de Ciencias da Nutricao e Alimentacao da Universidade do Porto, Instituto do Consumidor, 2003.

13 Aranceta J, Serra-Majem L: Dietary guidelines for the Spanish population. Public Health Nutr 2001;4:1403-1408.

14 Ett halvt kilo om dagen! Uppsala, Livsmedelsverket, 2003

15 Institute FHP: The Flemish Food Guide Pyramid. Ghent, Institute FHP, 2004.

16 Kersting M, Alexy U, Rothmann N: Fakten zur Kinderernährung. München, Hans Marseille Verlag, 2003, p 72.

17 Recommendations for Fruit and Vegetable Intake for Children. Uppsala, Statens Livsmedelsverk, 2004.

18 Perez-Rodrigo C, Ribas L, Serra-Majem L, Aranceta J: Food preferences of Spanish children and young people: the enKid study. Eur J Clin Nutr 2003;57(Suppl 1):S45-S48.

19 Andersen LF, Overby N, Lillegaard IT: Intake of fruit and vegetables among Norwegian children and adolescents. Tidsskr Nor Laegeforen 2004;124:1396-1398.

20 Eriksen K, Haraldsdottir J, Pederson R, Flyger HV: Effect of a fruit and vegetable subscription in Danish schools. Public Health Nutr 2003;6: 57-63.

21 Vasdeki VG, Stylianou S, Naska A: Estimation of age- and gender-specific food availability from household budget survey data. Public Health Nutr 2001;4:1149-1151.

22 Young People's Health in Context: International report from the HBSC 2001/02; in Currie $\mathrm{C}$ (ed): Health Policy Series: Health Policy for Children and Adolescents Issue 4. Copenhagen, WHO Regional Office for Europe, 2004.

23 Haraldsdóttir J, Thórsdóttir I, de Almeida MDV, Maes L, de Rodrigues C, Elmadfa I, Andersen LF: Validity and reproducibility of a precoded questionnaire to assess fruit and vegetable intake in European 11- to 12-year-old schoolchildren. Ann Nutr Metab 2005;49: 221-227.
24 Wind M, Bobelijn K, De Bourdeaudhuij I, Klepp K-I, Brug J: A qualitative exploration of determinants of fruit and vegetable intake among 10- and 11-year-old schoolchildren in the Low Countries. Ann Nutr Metab 2005;49:228-235.

25 Serra-Majem L, Ribas-Barba L, Pérez-Rodrigo C, Roman-Vinas B, Aranceta Bartrina J: Hábitos alimentarios y consumo de alimentos en la población infantil y juvenil española (19982000): variables socioeconómicas y geográficas. Med Clin (Barc) 2003;121:126-131.

26 Steingrimsdottir L, Thorgeirsdottir H, Aegisdottir S: Hvad bordar islensk aeska? Könnun á mataraedi ungs skolafolks 1992-1993. Rannsoknir Manneldisrads Islands IV. Reykjavik, Iceland, 1994.

27 Fagt S, Matthiessen J, Trolle E, Lyhne N, Christensen T, Hinsch HJ, Biltoft-Jensen A, Möller A, Daae AS: Danskernes kostvaner 2000-2001. Födevare Rapport 2002:10. Köbenhavn, Födevaredirektoratet, 2002.

28 Becker W: Befolkningens kostvanor och näringsintag i Sverige 1989. Uppsala, Statens Livsmedelsverk, 1994.

29 Riksmaten 1997-1998. Kostvanor och näringsintag i Sverige. Metod- och resultatanalys. Uppsala, Livsmedelsverket, 2002.

30 Andersen A, Due P, Poulsen LH, Rasmussen M: Sundhedsvaner; in Due P, Holstein BE (eds): Skoleboernsundersoegelsen 2002. Koebenhavn, Koebenhavns Universitet, Institut for Folkesundhedsvidenskab, 2003.

31 Trichopoulou A, Naska A: European food availability databank based on household budget surveys: the Data Food Networking initiative. Eur J Public Health 2003; 13(3 Suppl):2428.

32 FAO: Food Balance Sheets, FAOSTAT. Rome, FAO, 2002.

33 Hunt C, Nichols RN, Pryer JA: Who complied with national fruit and vegetable population goals? Eur J Public Health 2000;10:178-184. 